\title{
A Model of Monetary Transmission Mechanism
}

\author{
Yuuki Maruyama
}

\begin{abstract}
The point of this model is that total investment in the economy is not determined by the equilibrium of the interest rate alone, but by the equilibrium of both the interest rate and the market price of risk (risk premium). In this model, the lower the discount rate or risk aversion of people, the higher the total investment. This model shows that when the interest rate is not at the zero lower bound, the total investment is only slightly affected by people's risk aversion, but at the zero lower bound, the total investment is inversely proportional to people's risk aversion. In addition, this model is used to analyze monetary policy. It is shown that the interest rate channel and the credit channel can be analyzed with the same formula and the effect of the interest rate channel is small. This explains why a central bank can greatly increase the total investment with small changes in the interest rate. Additionally, this paper analyzes fiscal policy, helicopter money, and government bonds.
\end{abstract}

(JEL Classification: E22, E32, E44, E50, E52, E62, G10, H63)

このモデルのポイントは、経済における総投資量が利子率という 1 変数の均衡によって決 まるのではなく、利子率とリスクの市場価格（リスクプレミアム）という 2 変数の均衡によ って決定される点である。人々の時間割引率が低いほじ、そしてリスク回避度が低いほど、 経済における総投資量は増加することが示される。また、このモデルを用いると、ゼロ金利 制約下にない場合には総投資量は人々のリスク回避度の影響をあまり受けないが、ゼロ金 利制約下においては総投資量が人々のリスク回避度に反比例することが示される。加えて、 このモデルを用いて金融政策についても分析を行う。金利チャネルと信用チャネルが同一 の式で扱えることを示し、金利チャネルによる効果が小さいことを示す。これにより、中央 銀行が小さな利子率の変化で総投資量を大きく増やすことができる理由を説明する。また、 このモデルを用いて、財政政策・ヘリコプターマネー・国債発行についても分析する。 


\section{1 序論}

投資について扱っている経済学のモデルとしては、マクロ経済学のモデルと金融経済学 のモデルが存在する。しかし、両モデルにはそれぞれメリットとデメリットが存在する。

マクロ経済学のモデルにおいては、資本市場の需要曲線と供給曲線を考えることができ るため、経済においてなされる設備投資の総量を分析することができる。しかしその代わり、 多くのモデルにおいては投資というのは利子率という 1 変数によって決まると設定されて おり、投資のリスクについて考えることができていない。

それに対して、金融経済学のモデルにおいては投資のリスクも扱うことができており、利 子率とリスクの市場価格の 2 変数が均衡するような形で資本市場の需要曲線が決まってい る。しかしその代わり、資本市場の供給曲線を扱うことができない。証券の量を所与として その上でそれぞれの証券がどのくらいの市場価格になるかというモデルとなっているが、 経済における設備投資の総量を考えるには資本市場の供給曲線を考える必要がある。

今回はその両モデルのデメリットを解消し、投資を利子率とリスクの市場価格の 2 変数 で扱うことができ、なおかつ経済においてなされる設備投資の総量を分析することができ るモデルを考える。

設備投資というのは、まず第一期に資本財を購入し、その後毎期ごとにその資本財と労働 力を用いて財を生産し、その生産財のうちの一部を受け取るというものである。この際、投 資家に要求されるものは 2 つる。1つは現在消費を減らすことである。資金の支払いが今 期に行われ、資金の受け取りは来期以降に行われるため、将来消費のために現在消費を減ら 寸ことが求められる。もう 1 つはリスクテイクである。設備投資によって得られる収益に は不確実性が存在するため、その不確実性を受け入れることが求められる。

このように投資には 2 つのものが要求されるわけであるが、その 2 つ分離することが 可能である。株式と債券という 2 種類の証券を用いてそれが行われる。現在消費を減らし てもよいがリスクは負いたくないという場合は債券が購入され、現在消費の減少も投資の リスクもどちらも受け入れることができるという場合は株式が購入されることになる。今 回のモデルでもこのような形で投資を株式と債券に分けて扱う。リスク回避度が高い人ほ ど、貯蓄に占める株式の割合は低くなる。

また、本モデルで金融政策についても分析を行う。金利チャネル (interest rate channel) と信用チャネル (credit channel) が同一の式で分析できることを示し、金利チャネルによ る効果が小さいことを明らかにする。これにより、中央銀行が小さな利子率の変化で総投資 量を大きく増加させることができる理由を説明する。

さらに、今回は経済がゼロ金利制約下にある場合の分析も行う。この場合は、投資量はリ スクの市場価格の 1 変数が均衡するように決まることになる。そして、投資量は人々のリ スク回避度に反比例する。

また、投資量を増加させる上で、中央銀行による株式の購入・ヘリコプターマネー・財政 
政策などが有効であることを示す。さらに、国債発行についても言及する。

（本モデルの内容の詳細は 3 節の「結論」参照）

投資にはリスクがあるため貯蓄の全てが投資されるわけではない、ということについて は Tella（2018）などの先行研究が詳しい。この論文においては、貨幣が存在するせいで安 全利子率が負になることができず、貯蓄の内で投資に回らない部分が発生してしまう、とい うことについて述べられている。

また、リスクを伴う投資についての既存のモデルの多くは、負債比率の大きさを任意に決 められるとしており、負債比率は外生的に決まる值となっている。今回のモデルでは担保制 約とサンクコストの概念を組み合わせることで負債比率の大きさが一意に決まるようにし た。これにより、リスクの市場価格やその他多くの変数が内生的に決まるようになる。さら に、中央銀行による債券の買いオペレーションも扱えるようになる。

\section{2 モデル}

このモデルでは人々は毎期ごとに所得を受け取り、それを消費と貯蓄に分ける。貯蓄率や 貯蓄の資産構成は、利子率とリスクの市場価格とに基づいて決めることになる。その総計と して社会の総投資量が決定される。

資産の種類として、株式・債券・貨幣の 3 つが存在する。事業のリスクは全て株主が負担 することとし、債権者は株主から毎期ごと定率で利子を受けとる。加えて、債権者の元本は 保全されるものとする。そのため、資本財の内のサンクコストの割合をととすると、債権者 の元本が守られる（債券が安全資産となる）ためには、負債比率が $1-\varepsilon$ 以下でなければな


選択すればよいことになる。今回のモデルでは全ての企業の負債比率が $1-\varepsilon$ であるとする。

つまり、このモデルにおいては、株式と債券の違いは、利益率が毎期一定か否かという点 と、元本が保全されているか否かという点、との 2 点に存在する。今回のモデルは MM 理 論の前提とは異なり、設備投資のサンクコストを考慮するため、負債比率が一意に定まって も問題ない。

今回のモデルにおいては、企業の倒産は考慮しないものとし、その代わり株主の各期の配 当額は負にもなりうるものとする。（負の配当額は、資本金の取り崩しや増資とみなせる）

すべての投資案件は、投資の収益率の期待值が $g$ 、投資の収益率の標準偏差が $\sigma$ 、投資の サンクコストの割合が $\varepsilon$ であるとする。人々の貯蓄ストックの総額を $A$ とし、今期の貯蓄額 を $S$ とする。また、資本の総量を $K$ 、今期の投資量を $I$ 、株式投資の利益率の期待值を $R$ 、 債券投資の利益率を $r$ とし、人々のリスク回避度を $\gamma$ 、株式の保有割合を $\alpha$ とする。

資本の変化量については、 $\Delta K \ll K$ とする。また、単純化のために、各期の総供給 $Y$ は一 
定であるとする。資本財生産を $I$ だけ行い、消費財生産を $Y-I$ だけ行うことになる（つま り今回のモデルにおいては、資本財の生産が増えれば消費財の生産量は減ってしまうこと になるが、これを好景気と呼ぶことにする）。

株主は、 $\varepsilon K$ の資金を供給していることになるが、一期分の配当総額の期待值は $\varepsilon R K$ で、 一期分の配当総額の標準偏差は $\sigma K$ となる。そのため、株式投資の利益率は、期待値 $R$ 、標 準偏差 $\frac{\sigma}{\varepsilon}$ となる。

この值を用いて $z$ を

$$
z=\frac{(R-r)^{2}}{2\left(\frac{\sigma}{\varepsilon}\right)^{2} \gamma}+r
$$

と定義すると、Merton(1971）より、Aや $S$ は、時間割引率、異時点間の消費の代替の弾力性 $\left(=\frac{1}{\gamma}\right) 、 z$ の 変数関数として表せる。

また、株式の保有割合 $\alpha$ は

$$
\alpha=\frac{R-r}{\left(\frac{\sigma}{\varepsilon}\right)^{2} \gamma}
$$

となる。

\section{1 ゼロ金利制約下にない場合}

まず、ゼロ金利制約下にない場合を考える。利子率が正であるため、貨幣で貯蓄を行う理 由はなく、貯蓄は債券か株式でなされることになる。経済成長モデルや世代重複モデルなど の、貯蓄は必ず資本で行われるとするモデルと同じ状況となる。

株式の供給と株式の需要が一致するため、

$$
\varepsilon K=\alpha A
$$

債券の供給と安全資産の需要が一致するため、

$$
(1-\varepsilon) K=(1-\alpha) A
$$

株主の収益は、事業による収益から債券の利払い費を除いたものであるため、

$$
\varepsilon R K=g K-(1-\varepsilon) r K
$$

投資量は資本ストックの変化量なので、

$$
I=\Delta K
$$

貯蓄ストックの変化量は今期の貯蓄量と等しいため、

$$
S=\Delta A
$$


（1） (7)より、

$$
\begin{array}{lll}
r=g-\sigma^{2} \gamma & R=g+\frac{(1-\varepsilon) \sigma^{2} \gamma}{\varepsilon} & z=g-\frac{\sigma^{2} \gamma}{2} \\
\alpha=\varepsilon & K=A & I=S
\end{array}
$$

となる。

既存のマクロ経済学のモデルにおいては、投資は利子率という 1 変数が均衡するような 形で定まるとしているが、このモデルにおいては、投資は利子率とリスクの市場価格の 2 変 数が両方均衡するように定まることになる。 $r$ と $R$ の均衡值が決まることでその後、 $z \rightarrow$ $S \rightarrow I$ の順で決まっていき、投資量 $I$ が確定することになる。

また、 $r=g-\sigma^{2} \gamma$ より、ゼロ金利制約下にないための条件は $g \geq \sigma^{2} \gamma$ であるとが分か る。この条件を満たしている必要がある。

\section{＜金融政策＞}

ゼロ金利制約がない場合の公開市場操作について考える。 中央銀行による債券の買いオペレーションの量を $q$ とすると、

$$
(1-\varepsilon) K=(1-\alpha) A+q
$$

となり、この式を(4)の式の代わりに用いることになる。解を求めると、

$$
\begin{array}{lcl}
r=g-\sigma^{2} \gamma\left(1+\frac{q}{A}\right) & R=g+\frac{(1-\varepsilon) \sigma^{2} \gamma}{\varepsilon}\left(1+\frac{q}{A}\right) & z=g-\frac{\sigma^{2} \gamma}{2}\left\{1-\left(\frac{q}{A}\right)^{2}\right\} \\
\alpha=\varepsilon+\frac{\varepsilon q}{A} & K=A+q & I=S+q
\end{array}
$$

ここで、 $S$ も $q$ の関数であることに注意である。 $q \rightarrow r, R \rightarrow z \rightarrow S$ の順で、 $q$ によ り $S$ は増加する。

買いオペレーションによる投資量の変化について考察する。第 0 期から第 1 期にかけて 中央銀行が $q$ の量の買いオペレーションを行う場合、

$$
I_{1}-I_{0}=\left(S_{1}-S_{0}\right)+q
$$

となる。投資量の変化は $S$ による分と、 $q$ による分とに分けられる。前者はいわゆる、金融 政策の金利チャネル(interest rate channel) であり、後者は信用チャネル (credit channel) である。まず前者の金利チャネルのメカニズムについて述べる。中央銀行が債券の買いオペ レーションを行うと $r$ は低下寸る。債権者への利払い費が減るため株式の利益率 $R$ は上昇 し、 $Z$ は増加する。よって、 $S$ も増加し、 $S_{1}-S_{0}$ は正となる。これが金利チャネルによる金 融緩和効果である。それに対して後者の信用チャネルのメカニズムとしては、金融政策によ って民間の保有する債券の一部が貨幣に交換されると、人々は金利ゼロの貨幣ではなく株 
式や債券で資産を保有しようとするために、新たに投資が行われることになるというもの である。増えた貨幣のうち $1-\varepsilon$ が債券投資として使われ、 $\varepsilon$ が株式投資として使われるこ とになる。その結果、経済全体として見ると、資本財の生産量が増加し消費財の生産量は減 少する。

現実の経済においては多くの場合、消費量の異時点間の代替の弾力性 $\left(=\frac{1}{\gamma}\right)$ は低いため、 $\frac{\partial S}{\partial z}$ は小さく、 $S_{1}-S_{0}$ も小さい。そのため、 $I$ の増加に対して $S_{1}-S_{0}$ が寄与する部分は少な い。ほとんどは $q$ に由来すると言えるだろう。つまり、中央銀行の公開市場操作において重 要なのは、 $r$ を低下させ $S_{1}-S_{0}$ を大きくすることよりも、 $q$ を発生させることであると言え る。言い換えれば、金融政策は金利チャネルよりも信用チャネルを通して投資量を増やして いると考えられる。

ただ、中央銀行が金融政策のターゲットとして $r$ を用いることには合理性があると考えら れる。というのも、S の変動が小さいとみなせるとして式変形をし、 $q$ を消去すると、I は下 記の式で表されることになる。

$$
I_{1}-I_{0}=\frac{r_{0}-r_{1}}{\sigma^{2} \gamma} S
$$

つまり、投資量は利子率によって決まることになる。金融政策は $r$ の低下ではなく $q$ の発生 によって効果が発揮されるのだとしても、金融政策の目標として $r$ は明確で使いやすい指標 である。

また、金融政策が消費財と資本財の生産量へ及ぼす効果を考える。金融政策実行前は、消 費財の生産量が $Y-S$ 、資本財の生産量が $S$ であったが、金融政策を行うことで、消費財の 生産量が $\frac{(Y-S) Y}{Y+q}$ へと減り、資本財の生産量が $\frac{(q+S) Y}{Y+q}$ へと増えることになる $\left(\frac{\partial S}{\partial z}\right.$ は小さく、 $S$ は変化しないとみなせるため)。

また、

$$
\begin{aligned}
\alpha A & =\varepsilon A+\varepsilon q \\
(1-\alpha) A & =(1-\varepsilon) A-\varepsilon q
\end{aligned}
$$

となることから分かるように、債券の買いオペレーションによって、民間の貯蓄においては 株式の保有量が $\varepsilon q$ だけ増え、債券の保有量が $\varepsilon q$ だけ減ることになる。

本モデルでは直接金融で考えたが、銀行という間接金融でもこの状況を考えてみる。中央 銀行が市中銀行の安全資産を買うと、市中銀行は新たに貨幣を手に入れることになり、市中 
銀行は高リスクな融資を増やすことになる。もしくは、市中銀行がそのような行動をとらな い場合は、預金の利息が下がることになるため、預金者は預金を引き出してリスク資産を購 入するようになる。2つのパターンは本質的には同じ事である。このどちらかが起こること によって再度均衡状態が保たれる。結果として、金融政策が行われる前と比べて投資量は増 える。つまり、間接金融についても直接金融と同じ結論が得られることになる。

またこの金融政策についての分析は、財政政策によるクラウディングアウトの分析にも 用いることができる。国債が安全資産とみなされている国においては、Fだけ国債を発行し て財政政策（公共投資）を行うと、

$$
(1-\varepsilon) K+F=(1-\alpha) A
$$

となる。これは先程の分析において $q=-F$ としたときと同じことになる。つまり

$$
I=S-F
$$

となり、民間の投資量は $F$ の分だけ減ることになる。（ただし、民間と政府の投資の両方を 合わせた投資量は変化しない)

\section{2 ゼロ金利制約下にある場合}

次に、ゼロ金利制約下にある場合について考える。ゼロ金利制約下にあるというのは、つ まり $g<\sigma^{2} \gamma$ となる場合である。この節においても、異時点間の消費の代替の弾力性は低い とし、A や $S$ は定数とみなせるとする。

ゼロ金利制約下にある場合は、人々はそれ以上債券を買わずに、同じく安全資産である貨 幣で貯蓄を行うようになるため、債券の利子率は負になることができない。そのため、債券 の供給と安全資産の需要とは一致しなくなり、(4)の式は成り立たなくなってしまう。ただ、 その代わりに $r=0$ が成り立つようになるため、連立方程式を解く際にはこれを用いる。方 程式を解くと、

$$
\begin{array}{ccc}
r=0 & R=\frac{g}{\varepsilon} & z=\frac{g^{2}}{2 \sigma^{2} \gamma} \\
\alpha=\frac{\varepsilon g}{\sigma^{2} \gamma} & K=\frac{g A}{\sigma^{2} \gamma} & I=\frac{g S}{\sigma^{2} \gamma}
\end{array}
$$

となり、先程と異なりおおむね $I$ は $\frac{g}{\sigma^{2} \gamma}$ に比例することになる。ゼロ金利制約下にない場合 と異なり、 $\gamma$ が減少した場合に投資量が大きく増加すると言えるであろう。 


\section{<金融政策 $>$}

次に、ゼロ金利制約下にある場合の金融政策について考える。先ほどと同じように、 $r=$ 0 を(4)の式の代わりに用いることになる。安全利子率が 0 の時、債券の買いオペレーショ ン（量的緩和）は、利子率ゼロの安全資産同士の交換であるため、全く影響を与えない。債 券の買いオペレーションは効果がないと言える。ただし、株式の買いオペレーションであれ ば効果がある。株式の買いオペレーションの量を $Q$ とすると、 $\varepsilon K=\alpha A+Q$ となり、この式 を(3)の式の代わりに用いることになる。

この場合、 $K$ と $I$ の值のみが変化することになり、他の変数は金融政策実施前と変わらない ことが分かる。 $K, I$ を求めると、

$$
K=\frac{g A}{\sigma^{2} \gamma}+\frac{Q}{\varepsilon} \quad I=\frac{g S}{\sigma^{2} \gamma}+\frac{Q}{\varepsilon}
$$

となる。ゼロ金利制約下では株式の買いオペレーションを行うと、買いオペレーションの額 の $\frac{1}{\varepsilon}$ 倍分（つまり買いオペレーションの額以上に）投資量は増えるということである。

この原理について述べる。株式の買いオペレーションにより、民間の貯蓄においてリスク 資産の割合が減少し安全資産の割合が増加する。人々はリスク資産の割合を $\alpha$ に戻すため に新規投資を行う（新規株式を購入する）ようになる。するとそれに加えて、これまで貨幣 として貯蓄されていた額の一部が、その新規投資のための債券を購入することに活用され るようになる。つまり、株式の買いオペレーションにより、株式投資・債券投資の両方とも 増えるということである。そのため、株式の買いオペレーション額の $\frac{1}{\varepsilon}$ 倍の量、社会全体 の投資量は増加する。

\section{くヘリコプターマネーと財政政策 $>$}

ゼロ金利制約が存在する場合でも、ヘリコプターマネーを用いれば投資量は増加する。定 期的にヘリコプターマネーが行われることが予想される場合、貨幣での貯蓄は徐々に減価 していくことになる。それ故に、その分のマイナス金利を用いるのと同じ効果が得られると いうわけである。例えば、インフレ率を $\pi$ にすることを目標にして定期的なヘリコプターマ


することになるため、利子率を $-\pi$ まで下げても債券の需要は存在することになる。よって、 (4)の式の代わりに $r=-\pi$ を用いることになる。解を求めると、

$$
\begin{array}{lll}
r=-\pi & R=\frac{g+(1-\varepsilon) \pi}{\varepsilon} & Z=\frac{(g+\pi)^{2}}{2 \sigma^{2} \gamma}-\pi \\
\alpha=\frac{\varepsilon(g+\pi)}{\sigma^{2} \gamma} & K=\frac{(g+\pi) A}{\sigma^{2} \gamma} & I=\frac{(g+\pi) S}{\sigma^{2} \gamma}
\end{array}
$$


ゆえに、S を定数とするなら、インフレ率の上昇により、投資量は $\frac{\pi S}{\sigma^{2} \gamma}$ の分だけ増えること が分かる。

また、今回はへリコプターマネーで考えたが、国債が安全資産とみなされている国におい ては、代わりに国債発行を用いることも可能である。インフレ率（安全資産の減価率）を $\pi$ へ誘導することを目標として、その水準分、毎期ごとに国は国債発行を行うとする。国債発 行によって得られた貨幣は政府支出に使われるものとする。つまり、民間が保有する安全資 産の量は $\pi$ の率で徐々に増えていくことになる。この場合にも、市場は安全資産が $\pi$ ずつ減 価していくことを織り込んで行動するようになるため、投資量は $\frac{\pi S}{\sigma^{2} \gamma}$ だけ増加することに なる。また、政府支出が公共投資である場合にはさらにその分も投資量に加わることになり、 公共投資額を $F$ とすると、民間と政府を合わせた投資量は $\frac{\pi S}{\sigma^{2} \gamma}+F$ だけ増えることになる。 （ただし、国債を発行してもそれが政府支出として使われない場合には、民間が保有する安 全資産の量は変化しないため、効果はない)

\section{＜政府の国債発行について＞}

ゼロ金利制約下にある場合、国債発行量にも影響を与えることになる。ゼロ金利制約下に ある場合のモデルにおいて、投資されずに貨幣で貯蓄されている額は $(1-\alpha) A-(1-\varepsilon) K$ であり、これを計算すると、 $\left(1-\frac{g}{\sigma^{2} \gamma}\right) A$ となる。つまり、国債が安全資産とみなされている 国においては、 $\left(1-\frac{g}{\sigma^{2} \gamma}\right)$ A の分は無利子で国債が発行できることになり、クラウディングア ウトも発生しない。これは、ゼロ金利制約があるせいで貨幣に貯蓄されていた分の金額を国 債に用いることができるからである。それ故に、社会のリスク回避度 $\gamma$ が高い場合ほど、無 利子で多くの国債を発行できることになる。

多くの場合、国債発行量を抑制しようという最も大きな動機は国債金利の上昇であるた め、国債金利が上昇しにくいほど国債発行量は多くなり、世代間格差は増大寸ることが予想 される。このように、社会のリスク回避度の大きさが世代間格差の大きさを規定することに なる。

また、社会のリスク回避度が急に低下寸る可能性についても注意が必要である。この場合、 民間の投資額が増加しゼロ金利制約下から抜け出すため、国債が安全資産としてみなされ 続けていても国債金利は上昇する。社会のリスク回避度が高い時に国債を発行しすぎると、 社会のリスク回避度が急に低下した場合に、借り換えのための国債の金利が高くなり、利払 
い費が急増する危険性がある。

\section{3 結論}

今回のモデルを通して、

<ゼロ金利制約下にない場合 $>$

・総投資量は安全利子率とリスクの市場価格の 2 変数が均衡するように決まる

・中央銀行が債券を買うことにより、総投資量が増える（金融緩和）

・金融緩和では金利チャネルと信用チャネルの二つの効果が働いているが、主に信用チャネ ルが重要な役割を果たしていると考えられる

・ただし、金融政策の指標として安全利子率は有効な指標である

・財政政策の実施により、全体の投資量は変わらないが、民間の投資量は減る（クラウディ ングアウト)

<ゼロ金利制約下にある場合 $>$

・人々のリスク回避度がある水準よりも高くなると、ゼロ金利制約下に入ることになる

・総投資量は、リスクの市場価格という 1 変数が均衡するように決まる

・総投資量は人々のリスク回避度に概ね反比例し、ゼロ金利制約下にない場合と比較して、

リスク回避度の上昇により総投資量は大きく低下する

・中央銀行が債券を購入しても投資量は変化しない。ただし、中央銀行が債券ではなく株式 を購入する場合は、総投資量は増加する

・ヘリコプターマネーや国債の発行を通じて安全資産の流通量を一定の比率で増加させる 場合、総投資量は増加する

・財政政策により総投資量は増加するが、それによるクラウディングアウトは発生しない

・国債発行量による世代間格差は、人々のリスク回避度によって規定される

・人々のリスク回避度が減少するほど、国債の金利が高くなり、利払い費が増加する

などが示された。

\section{4 補遺}

今回のモデルにおいては $r$ が負の值をとることができないとしたが、投資に対してピグー 
補助金をかけるという政策を行うなら、安全資産に負の利子率とかけるのと同じ効果が得 られると言えるだろう。この場合は、2.2 節のモデルではなく、2.1 節のモデルが当てはま ることになる。

また本モデルでは、ヘリコプターマネーが景気回復に有効であるとしたが、それはあくま で人々が安全資産として貨幣を使い続けるという仮定の下でのみである。インフレ率が一 定以上に高くなると、人々が安産資産として貨幣ではなく他の減価しない財を利用するよ うになるかもしれず、その場合は貨幣需要が急減しハイパーインフレーションが起こる可 能性がある。

加えて、エクイティプレミアムパズルについても述べる。このモデルによれば、エクイテ イプレミアム $R-r$ の大きさは、ゼロ金利制約下にない場合には $\frac{\sigma^{2} \gamma}{\varepsilon}$ 、ゼロ金利制約下にあ る場合には $\frac{g}{\varepsilon}$ とり、投資のサンクコスト割合や投資の利益率などの外生的な要因によって 定まるものとなる。よって、エクイティプレミアムが高くても問題はない。

また、今回のモデルは閉鎖経済のモデルであるため、資本の流出入が存在する開放経済で は成り立たないことに注意が必要である。

\section{References}

Bacchetta, P., Benhima, K., \& Kalantzis, Y. (2019). Money and capital in a persistent liquidity trap. Journal of Monetary Economics.

Eggertsson, G. B., \& Krugman, P. (2012). Debt, deleveraging, and the liquidity trap: A Fisher-Minsky-Koo approach. The Quarterly Journal of Economics, 127(3), 1469-1513.

Merton, R. (1971). Optimum consumption and portfolio rules in a continuous-time model. Journal of Economic Theory, 3(4), 373-413.

Tella, S. D. (2018). A neoclassical theory of liquidity traps (No. w24205). National Bureau of Economic Research. 